\title{
A Review of Cultural Added Value Research Based on Knowledge Mapping Analysis
}

\author{
Ni Yuan ${ }^{1}$ Yang Lu$^{1}$ Gao Yudong ${ }^{1}$ Cai Gongshan ${ }^{1}$ \\ ${ }^{1}$ Beijing Information Science and Technology University Graduate school of economics and management Beijing, China
}

\begin{abstract}
The enhancement of cultural added value to products is reflected in the level of personal cultural spiritual enjoyment, corporate cultural brand building and social cultural essence inheritance. Compared with ordinary products, the added value of products after incorporating cultural elements is the size of the product's cultural added value. At the same time, different components of cultural added value can meet different cultural needs of consumers and reach emotional consensus with consumers to some extent. This complex diversity of value realization helps to lay a good foundation for developing cultural brands with Chinese characteristics and transmitting excellent traditional Chinese culture.
\end{abstract}

\section{INTRODUCTION}

Due to the strong permeability of culture, the integration of culture with different carriers, such as film and television, can enhance the value of its material carrier and achieve value added, that is produce cultural added value. Cultural added value can not only meet people's demand for culture and improve customer loyalty, which has become one of the critical approach for businesses to win the favor of consumers, but also create unique cultural brand image and promote the economic development of the cultural industry. Classics such as "Nirvana in Fire" and "A Bite of China" praised by foreign netizens, which have proved the importance of cultural added value in enhancing China's international influence and delivering Chinese values.

However, China still has a long way to go before it become a real cultural country, we having rich cultural resources but not being able to take full advantage and exploit them effectively, so that some foreign productions use such elements with Chinese characteristics as Mulan and panda to develop films, and achieve considerable economic benefits. Therefore, with the goal of enhancing the added value of culture, the new forms of business integrating various technologies, such as the Internet and new media can achieve the transformation from resource advantage to economic advantage by deeply exploring cultural resources and scientifically condenzing cultural elements, so as to promote the economic transformation and upgrading of China's cultural and creative industries.

\section{Cluster analysis Of Research topics ON CULTURAL ADDED VALUE}

Keywords can highly condense the author's opinions and ideas, while the content covered by high-frequency keywords represents the research topic in this field to some extent. This article deals with data related to the field of cultural added value and uses CiteSpace software to visually analyze keywords and deeply dig research content in related fields, it can show the research topic and research status of cultural added value. CiteSpace is a visualization software based on co-citation analysis theory and path-finding network algorithm, which is used by researchers for topic clustering analysis and keyword co-occurrence analysis ${ }^{[1][2]}$.

In order to explore the research topics in the field of cultural added value, this article uses CiteSpace software performs cluster analysis on selected literature keywords, and uses the software's related functions to adjust and optimize to enhance the readability of the map ${ }^{[3]}$. As shown in Figure 1, the keywords co-occurrence analysis is selected and keyword clusters are automatically generated. The realization of automatic clustering is to generate knowledge clustering based on spectral clustering algorithm, and then extract the tag words from the keywords of related literature to show the research topics in the field ${ }^{[4]}$. However, the keywords selected by clustering tags generated by automatic clustering are usually too specific to fully represent the content by the clustering. Therefore, only by specifically analyzing the contents contained and observing the connections among

ae-mail: niyuan230@163.com be-mail: 1046062198@qq.com ce-mail: 13161639206@163.com de-mail: 1033117679@qq.com 
each sub-cluster, can we have a more comprehensive understanding of the research topic in this field.

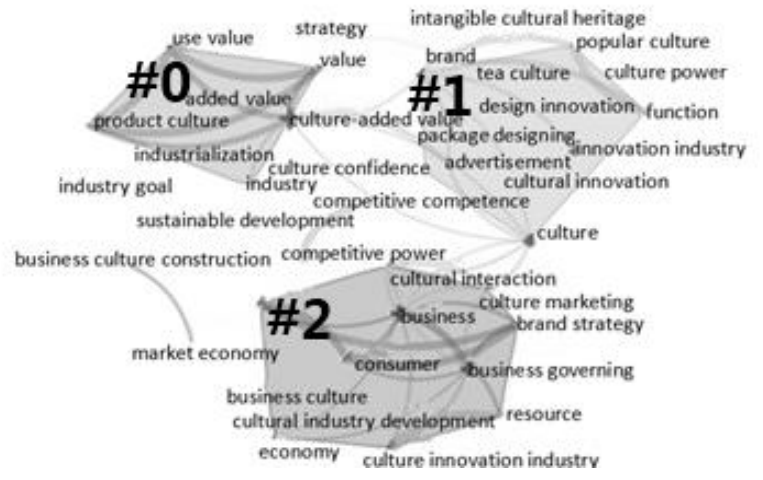

Figure 1. Clustering view of keywords

Using CiteSpace software to visually analyze highfrequency keywords in related literature of cultural added value, the results are shown in Figure1. The color of the lines between nodes represents the earliest cooccurrence time among keywords, and the thickness of the lines represents the height of co-occurrence. Thus, three sub-clusters are automatically generated, which are denoted by \#0, \#1 and \#2: (1) \#0: This sub-cluster mainly focused on the description of the cultural valueadded value system, but the cultural additional factors of commodities not only have value and use value, but also include the artistic value that emphasizes product function and the aesthetic value that focuses on customer psychology ${ }^{[5]}$. In addition, the value system of cultural added value is not unchangeable, it is affected by various factors. (2) \#1: Keywords covered in this sub-cluster include brand, advertising, design innovation, etc. Product designers give new meaning and value to products by using innovative development models, thus creating impressive products to express the ideas that they want to convey ${ }^{[6]}$. By integrating cultural elements into products and creating cultural products with Chinese characteristics, it can improve the cultural added value of products and enhance the building of cultural brands, which is also one of the important functions of cultural added value. (3) \#2: This sub-cluster contains keywords such as enterprise, consumer, and economy. Taking the cultural spiritual enjoyment of consumers as the starting point, enterprises build a cultural bridge for consumers through cultural creativity, and meet the cultural needs of consumers with diversity and diversity. Not only can it promote its own economic development, breed a batch of cultural brands with international influence, but also improve the competitive advantage of enterprises in the cultural market, so as to achieve the goal of building a cultural country.

To sum up, the contents covered in these three subclusters can reflect the current research topic. Combined with the visual analysis results, it is found that the research topic of cultural added value focuses on three aspects: how to define the meaning of cultural added value, how to build the value system of cultural added value, and the function and impact of cultural added value.

\section{Clustering themes of CUltural ADDED VALUE}

\section{A. Theme 1: How to define the meaning of cultural added value}

Cultural products may generate added value in the process of design, production, sales, and even after-sales service. Due to different perspectives, scholars have not yet reached a conclusion on the definition of cultural added value. As early as 1994, Diao Hongkuan, a domestic scholar, put forward a relevant definition, that is contains "In the three fields of production, circulation and consumption, all kinds of tangible and intangible cultural factors directly or indirectly attach to commodities, it increases the value of commodities over a period of time". However, the cultural added value of commodities is not unchanged, it changes with the consumer's living environment, national belief, living class and so on ${ }^{[7]}$. In addition, due to the different consumer's aesthetic orientation, product packaging design also has an impact on the level of cultural added value. Just as the lack of differentiated design can damage the overall image of the product, it will ultimately affect customer psychology and reduce shopping desire ${ }^{[8]}$. Therefore, goods' packaging design plays an important role in promoting the improvement of cultural added value, it can provide cultural added value in addition to the general functional value of products by injecting cultural concepts and innovative thinking ${ }^{[9][10]}$. The culture in packaging design not only refers to the traditional Chinese culture, but also is a feature of the times, which is influenced by product characteristics and customers' shopping ideas ${ }^{[9]}$.

He Xuefei proposed the view that "Non-functional value ${ }^{[11]}$ attached to commodities is cultural added value". According to the cultural phenomena and human psychological demand, the cultural connotation is integrated into the commodity to form a certain value concept by adding cultural symbol elements into the advertisement, which is interpreted as the cultural added value embodied in the product, it can reach an emotional consensus with consumers ${ }^{[12]}$. In addition, Yang Jinfang and Li Jianwei proposed that the cultural added value of advertising is attached to tangible products, which not only reflects the intangible cultural attributes and cultural connotations, conforms to the cultural psychology of the audience, but also plays an indispensable role in shaping the cultural brand image of enterprises ${ }^{[13]}$. Cultural brand can bring deeper cultural identity and spiritual sustenance to consumers. Chen Yonghua and Han Shuang believe that cultural added value is the intangible value that the brand adds to the value of cultural products in various forms, and it is the spiritual enjoyment of consumers on the basis of satisfying the material ${ }^{[14]}$.

In summary, the meaning of cultural added value can be defined from the description of its formation process, as shown in Figure 2. Cultural elements form cultural products through carriers, then they spread through specific ways to satisfy the cultural spiritual enjoyment 
of consumers, shape the unique cultural brand image of enterprises and Carry forward fine traditional culture.

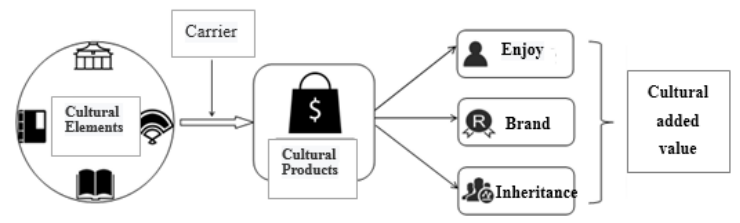

Figure 2. The formation process of cultural added value

\section{B. Theme 2: how to build a value system of cultural added value}

As for the research on the composition of cultural value-added value system, different scholars start from different perspectives, and the value composition obtained is a development process from four dimensions to multiple dimensions. The contents are shown in table I:

TABLE I. THE VALUE COMPOSITION OF CULTURAL ADDED VALUE

\begin{tabular}{|c|c|c|}
\hline Perspective & Value Composition & Author \\
\hline Form & $\begin{array}{c}\text { Art Value, Fashion Value, Service } \\
\text { Value, Brand Value }\end{array}$ & $\begin{array}{c}\text { Diao Hong } \\
\text { Kuan(1994) }\end{array}$ \\
\hline $\begin{array}{c}\text { Spiritual } \\
\text { Satisfaction }\end{array}$ & $\begin{array}{c}\text { Fashion Value, Aesthetic Value, } \\
\text { Spiritual Enjoyment Value, } \\
\text { Identification Value, } \\
\text { Symbolic Value }\end{array}$ & $\begin{array}{c}\text { Zhou Hai } \\
(2002)^{[9]}\end{array}$ \\
\hline $\begin{array}{c}\text { Tourism } \\
\text { Culture }\end{array}$ & $\begin{array}{c}\text { Fashion Value, Aesthetic Value, } \\
\text { Collection Value, Practical Value }\end{array}$ & $\begin{array}{c}\text { Zhao Bo } \\
(2005)^{[15]}\end{array}$ \\
\hline $\begin{array}{c}\text { Innovative } \\
\text { Market } \\
\text { Factor } \\
\text { Social Value, Market Value, } \\
\text { Appearance Value }\end{array}$ & $\begin{array}{c}\text { Artic Value, Entertainment Value, } \\
\text { Value, Aesthetic Value, Legacy, } \\
\text { Choice Value, Material Carrier Value, } \\
\text { Functional Value, Spiritual } \\
\text { Experience Value }\end{array}$ & $\begin{array}{c}\text { He Qi, Gao } \\
\text { Changchun } \\
(2013)^{[18]}\end{array}$ \\
\hline $\begin{array}{c}\text { Regional } \\
\text { Culture }\end{array}$ & $\begin{array}{c}\text { Artistic Value, Cultural Value, } \\
\text { Entertainment Value, Aesthetic Value }\end{array}$ & $\begin{array}{c}\text { XiuXiaodong, } \\
\text { Xu Qi, Feng } \\
\text { Xinqun } \\
(2016)\end{array}$ \\
\hline \multirow{2}{*}{$\begin{array}{c}\text { Value } \\
\text { Realization }\end{array}$} & $\begin{array}{c}\text { Artistic Aesthetic Value, Cultural } \\
\text { Value, Entertainment Value, } \\
\text { Historical Value, Scientific Value, } \\
\text { Educational Value, Moral Value, } \\
\text { Identity Value, Economic Value }\end{array}$ & $\begin{array}{c}\text { Tang Lixu } \\
(2018)^{[19]}\end{array}$ \\
\hline
\end{tabular}

The value system of cultural added value in Table I is originally composed of four dimensions. Due to different research perspectives, value systems of different dimensions are constructed to evaluate cultural added value. Domestic scholar Diao Hongkuan carried out his research from the perspective of two forms of the added value of commodity culture: one is the direct form, such as modeling and packaging, and the other is the indirect form, such as service quality and corporate image, the four-dimensional value system includes art value, fashion value, service value and brand value ${ }^{[5]}$. In addition, due to the cultural industry and tourism industry constantly fusion and development, many scholars began to focus their research on tourism culture. Zhao Bo think that the essence of tourism is cultural attribute, and the essence of tourism commodities is a cultural product, it can carry local characteristics and historical connotations, including practical value and collectible value ${ }^{[15]}$. Through tourism culture can also reflect regional cultural characteristics, the preference of tourists gradually from functional and material consumption mode to symbolic and spiritual experience $\operatorname{mode}^{[16]}$.

With the deepening of research, scholars have evolved a multi-dimensional cultural value added evaluation system based on different perspectives. From the perspective of satisfying satisfying customer spirit, Zhou Haiqing proposed that the value system of cultural value-added is mainly composed of the identification value, symbolic value and spiritual enjoyment value of product design ${ }^{[9]}$. This is because consumers pursue spiritual enjoyment reflected in a kind of commodity packaging with cultural taste, and it can reach a psychological consensus with consumers to some extent. However, improving the cultural added value of goods requires satisfying two requirements: one is uniqueness, so that the cultural connotation to be expressed in similar products is unique and creative; the other is persistence, which makes the product image deeply rooted in people's hearts through long-term communication and all-round penetration. Chen Qingdex believes that cultural products have the potential to transform into market exchange value and obtain multiple use values, such as social value and entertainment value ${ }^{[17]}$. Cultural creative products not only include material carrier value, functional value, and spiritual experience value. He Qi and Gao Changchun proposed that it also includes nonmarket, including social value, aesthetic value, bequest value ${ }^{[18]}$. In addition, Tang Lixu divided the intangible cultural heritage into three levels of material, behavior and spirituality ${ }^{[19]}$. Due to the complexity of value realization, he proposed that its value system includes historical value, educational value, cultural value and scientific value.

In a word, the value evaluation system of cultural added value is a process of evolution from four dimensions to multiple dimensions, in which artistic value, fashion value, cultural value and aesthetic value are often mentioned. The first three values emphasize the function of the product itself, including whether product design is innovative and whether cultural connotation is diverse. while aesthetic value is from the perspective of consumers, customer psychology and aesthetic tendency will also have an important impact on the evaluation of cultural added value.

\section{Theme3: the function and impact of cultural added value}

The function of cultural added value and its influence on individuals, enterprises or society is one of the main contents of scholars' research. As far as individuals are concerned, the degree of cultural added value to consumers' psychological satisfaction, which depends on how well the cultural elements match the consumers' own spiritual needs. For companies, building cultural brands can improve corporate awareness and customer loyalty, and promote corporate economic development 
${ }^{[20]}$. Culture can only play a role in society after being transmitted and received. Therefore, only by inheriting and developing China's outstanding traditional culture, can we enhance our country's cultural competitiveness in the international market ${ }^{[21]}$.

\section{- Personal cultural and spiritual enjoyment}

As the tangible attributes of products can meet consumers' functional needs, the cultural attributes attached to products can satisfy the spiritual needs of consumers, and cultural products have rich cultural connotations, so cultural production should fundamentally meet the growing spiritual and cultural demands of human beings [22][23]. The improvement of material level makes consumers' individual needs more and more obvious, through the analysis of the psychological characteristics of the consumers, we can understand the willingness of consumers to buy ${ }^{[24]}$. On this basis, Li Siqu proposed that the cultural connotation of modern goods should not only realize the spiritual satisfaction of consumers, but also recognize their social identity ${ }^{[25]}$.

Conversely, the cultural added value of products can be realized by stimulating consumers' cultural demand from the spiritual level, and thus promoting their purchase behavior [26]. Cultural products require consumer understanding and aftertaste, so cultural companies should pay more attention to understand customers' cultural needs, and strengthen customers' spiritual satisfaction and value recognition of cultural products, so as to effectively enhance the culture added value of product ${ }^{[27]}$.

\section{- $\quad$ Corporate Cultural Branding}

Brands have two kind of intrinsic cultural value and extrinsic cultural values. Only by introducing products with rich cultural connotation can we promote the building of cultural brand image. Lin Na take the brand construction of tourism destinations as an example, she explored the cultural value of tourism destinations from the aspects of historical culture and ethnic customs, enhancing the cultural experience of tourists to achieve the effect of strengthening the brand building of tourism culture ${ }^{[28]}$. In addition, not only the construction of tourism brand needs to pay attention to the excavation of national cultural spirit, other brands are also so. Shen Zhengzhong takes the animation brand as an example, and believes that the key to brand building lies in creating cartoon characters with national charm, thereby creating outstanding animation works that meet the spiritual and cultural needs of the people ${ }^{[29]}$.

Therefore, culture is the core of the brand, and the spiritual value in culture is consumers' high recognition of the brand' core value, and it is also a key link to shape the brand's lasting vitality ${ }^{[30]}$. The "Yang Asha" cultural brand construction is taken as an example by tapping social, historical, aesthetic, economic and other value connotations, it can enhance the cultural identity of consumers, and continuously deepen the brand impression ${ }^{[31]}$.

- Inheritance of the cultural essence of society

"Culture" is the outcome of human society, while "cultural inheritance" is the process of cultural reproduction, only by constantly learning and accepting the group culture can people establish themselves in the society ${ }^{[32]}$. The essence of cultural inheritance is to develop on the basis of inheritance and inherit in the process of development, it inherits a positive culture that can be used in modern times and promote social progress [21].

The inheritance and development of cultural essence is indispensable for spreading positive energy to the society and improving the soft power of national culture. One the one hand, cultural connotation in packaging design can increase the culture added value of commodity, so that it can improve the economic and commercial benefits of enterprises. On the other hand, cultural communication can provide norms of behavior and affect people's social values. In addition, the design of cultural products requires creativity, and the introduction of new ideas and new ideas can create a new consumer field for the market, it can promote the upgrading of enterprises and products, and create a good cultural atmosphere, which is conducive to the formation of a humanistic environment for talent gathering [10]. Cultural products are more deeply rooted in people's hearts than ordinary products, and heritage culture is to continue one's own values ${ }^{[13]}$.

\section{Conclusions ANd OUtLook}

In this paper, the literature review on the field of cultural added value was conducted by combining clustering analysis, summary and other methods. It is found that the research on cultural value added mainly focuses on three aspects: (1) the definition of cultural added value. Cultural products may generate cultural added value in the process of production, consumption, and after-sales service, so the cultural added value can be defined from the description of its formation process, that is cultural elements form cultural products through carriers, then they spread through specific ways to satisfy the cultural spiritual enjoyment of consumers, shape the unique cultural brand image of enterprises and Carry forward fine traditional culture. (2) The value composition of cultural added value. The research on the value evaluation system of cultural added value is a development process from four dimensions to multiple dimensions, which includes art value, fashion value, cultural value and aesthetic value. On this basis, due to the differences in research perspectives, different scholars evolve the multi-dimensional value evaluation index system. (3) The function and impact of cultural added value. The function of cultural added value is reflected from the individual to the enterprise and then to the society, in which the cultural spiritual enjoyment at the individual level is the premise, the cultural brand building at the enterprise level is the core, and the cultural essence inheritance of the society is the ultimate goal. They affect each other and complement each other, which is a high reflection of cultural added value.

Through the above analysis and summary of the field of cultural added value, it can be found that the current scholars' research on the field of cultural added value is still in preliminary stage. Therefore, this article proposes 
that the following three aspects can be studied in the future:

Firstly, build a more comprehensive value evaluation index system. Since cultural added value may be generated from the production to the sale of commodities, the influencing factors of cultural added value should be summarized in the future, and a more systematic value evaluation index system can be constructed by referring to the content of cultural added value.

Secondly, use a more objective value evaluation method. At present, the value evaluation of cultural added value is mostly carried out by case analysis and qualitative methods, which are subjective and lack of objectivity. Therefore, in the future, relevant evaluation index data can be obtained from the network platform to build an objective measurement model of cultural added value evaluation.

Thirdly, develop an intelligent pricing system for cultural products. As the current pricing method for cultural products is not much different from ordinary commodities. Therefore, in the future, we can explore the effects of different factors on cultural products through in-depth exploration, and develop an intelligent pricing system by using emerging algorithms such as machine learning to keep pace with The Times.

Fund project: National Key Research and Development Program Project "Service Value and Cultural Communication Evaluation Theory and Technology"(2017YFB1400400); Beijing Youth Top Talent Cultivation Project (CIT\&TCD 20180405); General Project of Science and Technology Plan of Beijing Municipal Education Commission (SM201611232002); Diligent Letter Talent Project (QXTCPC201706).

\section{REFERENCES}

1. Chen Yue, Chen Chaomei, Liu Zeyuan, Hu Zhigang, Wang Xianwen. Methodological Function of CiteSpace Knowledge Graph [J]. Scientific Research, 2015, 33 (02): 242-253.

2. Chen C. CiteSpace II : Detecting and Visualizing Emerging Trends and Transient Patterns in Scientific Literatur [J]. Journal of the American Society for Information Science and Technology, 2006, 57( 3) : $359-377$.

3. Yi C, Jian M, Liu Y. Knowledge Mapping of Social Commerce Research: A Visual Analysis Using Citespace[J]. Electronic Commerce Research, 2018, 18(88) : 1-32.

4. Shi Xiaocen, Li Manli. International MOOC Research Hotspots and Trends-Citespace Visual Analysis Based on 2013-2015 Literature [J]. Open Education Research, 2016, 22 (01): 90-99.

5. Diao Hongkuan. On the Cultural Added Value of Commodities and Its Development [j]. Journal of Guangxi Commercial College, 1994 (02): 27-29.

6. Chang W. District Resource: Culturally Creative Products Derived from a Local Legend[J]. International Journal of Art Culture \& Design Technologies, 2017, 4:32-41.

7. Jia Li. On the Cultural Added Value of Commodities [j]. Social Science Aspects, 1995 (03): 52-55.

8. Chen L. Appearance Design Research of Opera Animation \& Comic Cultural Product Illu-Strated By the Case of Opera Animation \& Comic[C]// 2017 International Conference on Applied System Innovation (ICASI). IEEE, 2017.
9. Zhou Haiqing. On the Construction of Commodity Culture by Packaging Design [j]. Journal of Changsha Civil Vocational and Technical College, 2002 (04): 78-80.

10. Wang Zhiping. Creative Products, Conceptual Value and Cultural Consumption [j]. Reform and Opening, 2009 (07): 141 +143 .

11. He Xuefei. On the Construction of Cultural Added Value in Advertising Communication [j]. Journalism, 2005 (04): 8890 .

12. Huang Zhihua. Semiotic Interpretation of Traditional National Cultural Elements in Modern Advertising Design [j]. Guizhou Ethnic Studies, 2018, 39 (02): 161-164.

13. Zhou Kai. Lack of Core Values, Construction and Transmission-Reflection on the Development of Chinese Cultural Industry and References to Western Cultural Industries [j] . Dongyue Theory, 2012, 33 (09): 5-14.

14. Chen Yonghua, Han Shuang. Research on the Added Value Promotion of Fuxin Agate Jade Culture[j]. Journal of Liaoning Technical University (Social Science Edition), 2016, 18 (05): 711-714.

15. Zhao Bo. On the Use of Culture to Increase the Added Value of Tourism Goods [j]. Consumer Economy, 2005 (02): 34-36.

16. Cheng L, Youhai LU, Dengli LI, et al. An Empirical Study on Culinary Tourism Destination Brand Personality and Its Impact in the Context of Confucian Culture[J]. Tourism Tribune, 2018.

17. Chen Qingde. The Value Judgment and Formal Expression of Cultural Products [j]. Ideological Front, 2007 (05): 21-34.

18. He Qi, Gao Changchun. On the Value Characteristics and Value Composition of Creative Products - Based on the Perspective of Market Value Realization [j]. Business Economics and Management, 2013 (02): 83-89.

19. Tang Lixu. Research on the Value System of Sports Intangible Cultural Heritage [j]. China Sport Science and Technology, 2018, 54 (03): 29-36 + 86 .

20. Guo Xiaoling, Zhang Mengxia. Research on the Motivation of Brand's Sensitive Cultural Values - On the Moderating Role of Product Benefit Attributes [j]. Research on Financial Issues, 2010 (11): 97-105.

21. Dou Kun, Liu Xinke. Contemporary Value and Inheritance of Chinese Traditional Culture[i]. Journal of Northwest A \& F University (Social Science Edition), 2010, 10 (03): 115-119.

22. Li Junqing. Relationship between Social Benefits and Economic Benefits of Products [j]. Theory and Reform, 1998 (02): 82-83.

23. He Xuefei. From "Commodity" as the Center to "Human" as the Center-Analysis of the Motivation of Advertising Culture's Value-added Appeal [j]. Journalism, 2006 (04): 98-99.

24. Wenting Chen, Qian Zhang, Maozhu Jin, Jie Yang. Research on Online Consumer Behavior and Psychology under the Background of Big Data[J]. Concurrency and Computation: Practice and Experience, 2019, 31(10).

25. Li Siqu. Dual Structure of Advertising Signs and Consumption [j]. Journal of Southwest University for Nationalities (Philosophy and Social Science Edition), 2000 (05): 119-122+ 159.

26. Yu Shasha. Analysis of the Influence of Consumer Cognition on the Cultural Value of Products[j]. Chinese and Foreign Entrepreneurs, 2012 (13): 72-73.

27. Guo Peng, Li Bing, Liang Huihuang. An Empirical Study on the Influence of Consumers' Purchase Behavior of Cultural Products-Taking Hunan Cultural Product Brands as Examples[j]. Hunan Social Science, 2014 (05): 153-156.

28. Lin Na. Cultural Value Choice and Creation of Brand Construction in Tourist Destinations-Taking Guilin International Tourist Resort as an Example [j]. Social Scientist, 2014 (11): 70-74.

29. Shen Zhengzhong. The Value of National Culture in Animation Brand Building [j]. China TV, 2017 (04): 110-112.

30. Duan Chunlin. From Instrumental Rationality to Value Rationality: A Study on the Promotion Strategy of Chinese Brand Spiritual Culture [j]. Nanjing Social Science, 2018 (09): 111-119. 
31. Wu Jiani. "Yang Asha" Cultural Value Dou Kun, Research on Liu Xinke's Excavation and Cultural Brand Construction [j]. Guizhou Ethnic Studies, 2018, 39 (04): 88-92.
32. Zhao Shilin. On the Essence of Inheritance of National Culture [j]. Journal of Peking University (Philosophy and Social Sciences), 2002 (03).10-16 